\title{
TRACE ELEMENTS IN SOME FINNISH PEGMATITIC POTASSIUM FELDSPARS
}

\author{
Rolf Lappalainen and K. J. Neuvonen \\ Institute of Geology, University of Turku, Finland
}

\begin{abstract}
Thirty eight potassium feldspar samples from pegmatites were analyzed for $\mathrm{K}, \mathrm{Na}, \mathrm{Ca}, \mathrm{Fe}, \mathrm{Rb}, \mathrm{Sr}, \mathrm{Cs}, \mathrm{Ba}$ and $\mathrm{Pb}$. The X-ray fluorescence method used and the distribution of the trace elements are described and discussed. Low $\mathrm{Ba}$, high $\mathrm{Rb}$ and $\mathrm{Cs}$ seem to be characteristic features of the Finnish Precambrian pegmatite feldspars.
\end{abstract}

\section{Introduction}

The typical trace elements in the feldspars of igneous rocks are well known. The alkali cations, $\mathrm{K}$ and $\mathrm{Na}$, are partially replaced by the large cations: rubidium, cesium, calcium, strontium and barium. Lead is also known to substitute for potassium in K-feldspars (Rankama and Sahama, 1950) and small amounts of iron are also frequently met with in feldspar analyses.

A comprehensive review of the trace elements in feldspars has been given by Heier (1962). This work and the papers by Heier and Taylor (1959 a and b) established the general rules concerning the distribution of trace elements in alkali feldspars. More recently, Herz and Dutra (1966) have studied trace elements in the alkali feldspars from Minas Gerais, Brazil. The purpose of the present work is to find possible variations in the trace element contents in the Finnish feldspars and to compare the values with those obtained in other areas.

\section{Samples}

The potassium feldspar samples for analysis were selected from the collections of the Institute of Geology, University of Turku. The main part of these samples was originally collected by Prof. Aarne Laitakari who donated his mineral collections to the new institute in Turku. Most of the samples were used for the analysis as such, since no impurities were observed. Some samples, however, were crushed and hand picked prior to the analysis. Perthitic feldspars and specimens with graphic quartz were ground for analysis without separation. A Labor-Scheiben Schwingmühle, Type T 100, with tungstencarbide covering was used for the final pulverizing of the samples.

\section{Method of chemical analysis}

The contents of $\mathrm{K}, \mathrm{Ca}, \mathrm{Fe}, \mathrm{Rb}, \mathrm{Sr}, \mathrm{Ba}, \mathrm{Pb}$ and $\mathrm{Cs}$ in the samples were determined by the $\mathrm{X}$-ray fluorescence method. A Philips universal vacuum spectrograph PW 1540/10 attached to an X-ray generator PW 1010/80 was used with W or Cr anode high-intensity $\mathrm{X}$-ray tubes and a flowproportional counter. LiF and ethylene diamine dextrotartrate (EDDT) crystals were used as analysers and the spectrograph was operated in vacuum except when analyzing $\mathrm{Fe}$ and $\mathrm{Rb}$ which were determined under atmospheric pressure in air. 
TABLE 1

The instrumental setting and the analytical lines used

\begin{tabular}{|c|c|c|c|c|c|c|c|c|c|}
\hline \multirow{2}{*}{ Element } & \multirow{2}{*}{$\begin{array}{l}\text { Line } \\
\text { used }\end{array}$} & \multirow{2}{*}{$\begin{array}{l}\text { Anal. } \\
\text { crystal }\end{array}$} & \multicolumn{2}{|c|}{$2 \theta$ setting } & \multirow{2}{*}{ Anode Type } & \multirow{2}{*}{$\mathrm{kV} / \mathrm{mA}$} & \multirow{2}{*}{$\begin{array}{l}\text { Collimator } \\
\text { setting }\end{array}$} & \multicolumn{2}{|c|}{ Counter } \\
\hline & & & analys. & backgr. & & & & Type & Volts \\
\hline $\mathrm{K}$ & $\mathrm{K} a$ & EDD'T & 50.31 & 52.20 & $\mathrm{Cr}$ & $40 / 10$ & coarse & Flow & 1650 \\
\hline $\mathrm{Ca}$ & $\gg$ & $\mathrm{LiF}$ & 113.11 & 114.75 & $》$ & » & $\gg$ & ) & ) \\
\hline $\mathrm{Rb}$ & $\gg$ & 》) & 26.58 & 27.70 & W & $\gg$ & Fine & Scinttil. & 900 \\
\hline $\mathrm{Fe}$ & $\gg$ & $»$ & 57.45 & 58.70 & 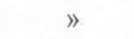 & $\gg$ & $\gg$ & 》) & ) \\
\hline Sr & $\gg$ & $\gg$ & 25.09 & 25.60 & ) & $50 / 16$ & $》$ & $\gg$ & $\gg$ \\
\hline Cs & $\gg$ & $\gg$ & 11.43 & 11.90 & $\gg$ & $50 / 18$ & $\gg$ & $\gg$ & $\gg$ \\
\hline $\mathrm{Ba}$ & $"$ & $》$ & 10.97 & 11.70 & $\gg$ & $\gg$ & $》$ & $\gg$ & $\gg$ \\
\hline $\mathrm{Pb}$ & $\left.\mathrm{L} \beta^{1}\right)$ & 》 & 28.22 & 28.70 & $\gg$ & $50 / 16$ & 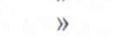 & $\gg$ & $\gg$ \\
\hline
\end{tabular}

1) $\mathrm{L} \beta$-line was used because of the coincidence of $\mathrm{Pb} \mathrm{L} \alpha_{1}$ and $\mathrm{As} \mathrm{K} \alpha_{1} \cdot \mathrm{L} \beta_{1-2}$ has the same $2 \theta$ value as second order $\mathrm{Sn} \mathrm{K} \alpha_{1}$ but the tin content of the feldspars analysed was estimated to be very small.

Conventional sample holders with thin Mylar windows were used. All samples and standards were packed and pressed by hand. Previously analysed feldspar powders, obtained from the geological Survey of Finland, were emloyed as standards for $\mathrm{Na}, \mathrm{K}, \mathrm{Ca}, \mathrm{Rb}, \mathrm{Ba}$ and $\mathrm{Pb}$. The working curves for $\mathrm{Cs}$ were calculated using $\mathrm{Ba}$ as an internal standard, and the $\mathrm{Sr}$ curve was plotted with $\mathrm{Rb}$ as the standard element. A Fe standard curve was plotted on the basis of colorimetric determinations.

The sodium contents were determined with a Jouan flame-photometre, S 295 E. For the determination, a $250 \mathrm{mg}$ sample was decomposed with $\mathrm{HF}$ and $\mathrm{HClO}_{4}$ in a platinum dish on a sandbath and twice evaporated to dryness. After one more evaporation, with $\mathrm{HC} 1$, the residue was dissolved in water and diluted to a $\mathrm{Na}_{2} \mathrm{O}$ content between $2-5 \mathrm{ppm} /$ litre.

Table 1 gives the analytical lines used and the instrumental settings. The pulse height distribution curves were scanned by an automatic device. The correct distriminator settings to be used were determined from these curves.

The counting time was $6 \times 40$ seconds for $\mathrm{K}$ and $\mathrm{Ca}$ and $3 \times 40$ seconds for the other elements. The net counting rate (line intensity minus back-ground intensity) was determined for each element in the samples and standards, and the trace element contents were calculated on the basis of the net counting rate rations (sample/ standard).

Table 2 lists the analytical results as oxide contents as well as some element ratios. Table 3 lists the standard and observed deviations for the analytical technique used. The standard deviation was calculated from

$$
\mathrm{s}=\sqrt{\frac{\sum \mathrm{x}_{\mathrm{i}}^{2}-\mathrm{N}_{\mathrm{x}}^{-2}}{(\mathrm{~N}-1)}}
$$

and the coefficient of variation $(\nu)$ from

$$
v=\frac{100 \mathrm{~s}}{\overline{\mathrm{x}}}
$$

in which

$\mathrm{x}_{\mathrm{i}}=$ the value of individual determination

$\mathrm{N}=$ the number of determinations

$\overline{\mathrm{x}}=$ the mean value of $\mathrm{N}$ determinations

\section{The results and conclusions}

The results obtained show that the trace elements in feldspars are determined with fair precision and accuracy and with greater convenience when the X-ray fluorescence method is employed. Many of the elements analyzed are difficult to determine by optical spectrography in 
TABLE 2

Alkali and trace element contents of analyzed potassium feldspars

\begin{tabular}{|c|c|c|c|c|c|c|c|c|c|c|c|c|c|}
\hline Locality & ${ }_{2} \mathrm{O}$ & $\mathrm{a}_{2} \mathrm{O}$ & $\mathrm{CaO}$ & $\mathrm{Fe}_{2} \mathrm{O}_{3}$ & $\mathrm{Rb}_{2} \mathrm{O}$ & $\mathrm{SrO}$ & $\mathrm{C}_{2} \mathrm{O}$ & $\mathrm{aO}$ & $\mathrm{PbO}$ & $\mathrm{K} / 1$ & $\mathrm{a} / \mathrm{Rb}$ & Sr & $\mathrm{T}$ \\
\hline \multicolumn{14}{|l|}{ Soutb-western Finland } \\
\hline Kemiö & 12.31 & 2.80 & 0.07 & 0.05 & 0.42 & 0.003 & 0.003 & 0.000 & 0.005 & 27 & 0.00 & 0.00 & 550 \\
\hline ärr, Kemiö & 12.47 & 2.71 & 0.10 & 0.06 & 0.07 & 0.006 & 0.000 & 0.013 & 0.008 & 173 & 0.20 & & 545 \\
\hline Skinnarvik, Kemiö ......... & 12.00 & 3.10 & 0.08 & 0.04 & 0.40 & 0.003 & 0.008 & 0.000 & 0.004 & 27 & 0.00 & 0.00 & 580 \\
\hline $\begin{array}{l}\text { Rosendal, Kemiö .......... } \\
\text { Soutbern Finland }\end{array}$ & 9.88 & 4.33 & 0.17 & 0.07 & 0.23 & 0.005 & 0.000 & 0.002 & 0.004 & 39 & 0.01 & 0.50 & 680 \\
\hline Paavo, Orijärvi, Kisko ...... & 12.68 & 2.37 & 0.08 & 0.05 & 0.31 & 0.003 & 0.000 & 0.010 & 0.006 & 38 & 0.03 & 3.00 & 515 \\
\hline aari, Tammela ......... & 9.07 & 2.68 & 0.11 & 0.06 & 0.09 & 0.003 & 0.000 & 0.002 & 0.007 & 94 & 0.03 & 0.67 & 540 \\
\hline nmäki, Tammela ....... & 11.63 & 3.25 & 0.10 & 0.07 & 0.08 & 0.005 & 0.000 & 0.002 & 0.006 & 138 & 0.03 & 0.50 & 590 \\
\hline , Tammela ........... & 8.99 & 2.60 & 0.09 & 0.10 & 0.08 & 0. & & 0. & 0 . & 107 & 0.03 & & 535 \\
\hline mäki, Somero ........ & 11.83 & 2.60 & 0.05 & 0.02 & 0.05 & & & & & 194 & 2 & & 535 \\
\hline ro $\ldots \ldots \ldots \ldots \ldots \ldots \ldots$ & 12.65 & 2.56 & 0.06 & & & & & & & 131 & & & 530 \\
\hline yrkan, Tammisaari ..... & 12.32 & 2.88 & 0. & & & & 0.000 & & & 102 & & 0 & 560 \\
\hline $\begin{array}{l}\text { Sillböle, Helsinki .......... } \\
\text { Soutb-eastern Finland }\end{array}$ & 11.81 & 3.32 & 0.20 & 0.10 & 3 & & & 0. & & 327 & 2.43 & 9.12 & 600 \\
\hline Ihalainen, Lappeenranta & 12.16 & 2.18 & 0.26 & 0.08 & 1.69 & 0.005 & 013 & 0.005 & 0.009 & 7 & 0.00 & 1.00 & 495 \\
\hline & & 4.24 & 0.41 & 0.03 & 0.17 & 0. & & 3 & & 54 & 7 & 0 & 675 \\
\hline Lähdemäki, Pitkäranta ...... & 8.97 & 2.53 & 0.11 & 0.14 & 0.07 & 0. & 0. & 3 & 0. & 124 & 5 & 0 & 530 \\
\hline Lupikko, Pitkäranta ........ & 11.43 & 2.54 & 0.13 & 0.03 & 0.10 & 0.005 & 0. & 0 & & 105 & 0 & 5 & 530 \\
\hline $\begin{array}{l}\text { Pälkjärvi } \ldots \ldots \ldots \ldots \ldots \ldots \\
\quad \text { Central Finland }\end{array}$ & 11.89 & 3.09 & 0.05 & 0.03 & 0.11 & 0.002 & 0. & 0.001 & 0.006 & 99 & 0.01 & 0.50 & 580 \\
\hline Västilä, Längelmäki . . & 12.59 & 2.63 & 0.03 & 2 & 9 & 0.003 & 0.011 & 0.000 & 0.006 & 61 & 0.00 & 0.00 & 535 \\
\hline la, Kanga & 5 & 4.75 & 0.23 & 0.11 & 0.21 & 6 & & & & 40 & 5 & 2.00 & 730 \\
\hline niemi, Eräj & 12.59 & 2.31 & 0.12 & 0.03 & 0.32 & 0.003 & & & & 36 & 0 & 0.00 & 510 \\
\hline Churchvillage, Eräjärvi ..... & 05 & 2.63 & 0.17 & 0.04 & 0.42 & 0. & & & & 26 & 0.06 & 5.25 & 535 \\
\hline $\begin{array}{l}\text { Seppälä, Eräjärvi } \ldots \ldots \ldots \ldots \\
\text { Western Finland }\end{array}$ & 12.91 & 1.99 & 0.20 & 0.04 & 0.30 & 0.004 & 0.057 & 0.000 & 0.005 & 40 & 0.00 & 0.0 & 480 \\
\hline - & 12.50 & 2.32 & 0.06 & 0.07 & 0.06 & 0.011 & 0.005 & 0.052 & 0.006 & 208 & 0.94 & 5.22 & 510 \\
\hline Kaatiala, Kuortane ......... & 11.65 & 3.31 & 0.06 & 0.02 & 0.31 & & 0. & & & 35 & .00 & $\begin{array}{l}0.00 \\
0.00\end{array}$ & 600 \\
\hline$\ldots \ldots \ldots$ & $\begin{array}{l}12.87 \\
11.85\end{array}$ & $\begin{array}{l}1.84 \\
2.25\end{array}$ & $\begin{array}{l}0.10 \\
0.06\end{array}$ & $\begin{array}{l}0.01 \\
0.03\end{array} \mid$ & 1.03 & 0. & 0.0 & & & $\begin{array}{l}11 \\
82\end{array}$ & .00 & $\begin{array}{l}0.00 \\
2.50\end{array}$ & $\begin{array}{l}465 \\
505\end{array}$ \\
\hline $\begin{array}{c}\text { " } \\
\text { Haapaluoma, Peräseinäjoki } \ldots .\end{array}$ & $\begin{array}{l}11.85 \\
12.37\end{array}$ & $\begin{array}{l}2.25 \\
2.77\end{array} \mid$ & $\begin{array}{l}0.06 \\
0.06\end{array}$ & $\begin{array}{l}0.03 \\
0.03\end{array}$ & $\begin{array}{l}0.13 \\
0.11\end{array} \mid$ & 0.0 & & 0.008 & 0.006 & 103 & .07 & 2.33 & 550 \\
\hline Emmes, Alaveteli .......... & 13.18 & 1.95 & 0.41 & 0.03 & 0.30 & & & 0.005 & 0.006 & 41 & 0.02 & 1.00 & 47 \\
\hline$\ldots \ldots \ldots \ldots$ & 11. & 2.32 & 0.42 & 0.03 & 0.35 & & & 0.003 & 0.006 & 30 & 0.01 & 0.75 & 51 \\
\hline Alaveteli . & 11. & 2.3 & 0.27 & 0.06 & 0.26 & & & & 0 . & 41 & 0.00 & 0.00 & 51 \\
\hline stinen $\ldots \ldots \ldots \ldots$ & 11. & 2.3 & 0. & 0. & 0. & & & & & 31 & 0.00 & 0.00 & 51 \\
\hline Pränsö, Kaustinen .......... & 9.67 & 2.67 & 0.11 & 0.14 & 0.07 & & & 0.004 & 0. & 134 & 0.07 & 1.33 & 54 \\
\hline $\begin{array}{l}\text { Törnävä, Seinäjoki ......... } \\
\text { Foreign samples for comparison }\end{array}$ & 10.36 & 2.78 & 0.15 & 0.04 & 0.06 & 0.006 & 0.006 & 0.016 & 0.007 & 172 & 0.28 & 2.80 & $=5$ \\
\hline Sweden & 12.73 & 1.89 & 0.23 & 0.02 & 0.86 & 0.002 & 0.010 & 0.000 & 0.004 & 13 & 0.00 & 0.00 & 470 \\
\hline & 11.89 & 2.59 & 0.12 & 0.02 & 1.17 & 0.003 & 0.420 & 0.000 & 0.004 & 9 & 0.00 & 0.00 & \\
\hline le, & 12.32 & 2.60 & 0.07 & 0.06 & 0.15 & 0.009 & 0.000 & 0.016 & 0.009 & 73 & 0.10 & 1.75 & \\
\hline , Norway ... & 12.01 & 2.91 & 0.12 & 0.09 & 0.12 & 0.005 & 0.000 & 0.008 & & 91 & 0.06 & 1.75 & 0 \\
\hline Weiden, Bavaria & $|11.55|$ & $|2.97|$ & 0.04 & 0.04 & $\mid 0.29$ & 0.000 & $|0.000|$ & $0.001 \mid$ & 0.004 & 36 & 0.00 & 0.00 & \\
\hline
\end{tabular}

small amounts because of low sensitivity, high volatility or because of interference (Ahrens and Taylor, 1961). Also K, Ca and Fe can be determined with at least reasonable if not good accurasy with the fluorescence technique. The stand- ard materials, however, should be as reliable as possible. In this respect, the standards used in the present work were not fully satisfactory.

Potassium, sodium and calcium vary considerably in the material analyzed indicating vari- 
Table 3

Standard deviation, variance and maximal deviations observed.

\begin{tabular}{|c|c|c|c|c|}
\hline & & \multicolumn{2}{|c|}{ Standard deviation $(\mathrm{N}=4)$} & \multirow{2}{*}{$\begin{array}{l}\text { Maximal } \\
\text { deviation } \\
\text { observed } \\
\text { (per cent) }\end{array}$} \\
\hline & & $\begin{array}{c}\text { numerical } \\
(\mathrm{s})\end{array}$ & $\begin{array}{c}\text { per cent } \\
(v)\end{array}$ & \\
\hline \multicolumn{5}{|c|}{$\mathrm{K}_{2} \mathrm{O}$} \\
\hline $8.87 \%$ & $\ldots \ldots \ldots$ & +0.032 & 0.4 & 1.1 \\
\hline $12.93 \%$ & $\ldots \ldots \ldots$ & +0.008 & 0.1 & 1.9 \\
\hline \multicolumn{5}{|l|}{$\mathrm{CaO}$} \\
\hline $0.05 \%$ & $\ldots \ldots \ldots$ & +0.0007 & 1.3 & 6.6 \\
\hline $0.41 »$ & $\ldots \ldots \ldots$ & +0.015 & 3.6 & 4.3 \\
\hline \multicolumn{5}{|c|}{$\mathrm{Fe}_{2} \mathrm{O}_{3}$} \\
\hline $0.039 \%$ & $\ldots \ldots \ldots$ & $\begin{array}{l}+0.0004 \\
+0.0035\end{array}$ & 1.0 & $\begin{array}{l}5.0 \\
4.9\end{array}$ \\
\hline $0.139 »$ & $\cdots \cdots \cdots$ & +0.0035 & 2.3 & 4.9 \\
\hline \multicolumn{5}{|l|}{$\mathrm{Rb}_{2} \mathrm{O}$} \\
\hline $0.057 \%$ & $\ldots \ldots$ & +0.0003 & 0.5 & 0.6 \\
\hline $0.418 ”$ & $\ldots \ldots \ldots$ & +0.0039 & 0.9 & 1.0 \\
\hline \multicolumn{5}{|l|}{$\mathrm{SrO}$} \\
\hline $0.004 \%$ & $\ldots \ldots \ldots$ & +0.0001 & 2.3 & 8.2 \\
\hline $0.012 》$ & $\ldots \ldots \ldots$ & +0.0001 & 0.8 & 1.1 \\
\hline \multicolumn{5}{|l|}{$\mathrm{Cs}_{2} \mathrm{O}$} \\
\hline $0.005 \%$ & & +0.0013 & 29.0 & 106 \\
\hline $0.059 \gg$ & $\ldots \ldots \ldots$ & +0.0012 & 2.1 & 2.7 \\
\hline \multicolumn{5}{|l|}{$\mathrm{BaO}$} \\
\hline $0.017 \%$ & . & +0.0003 & 1.7 & 9.2 \\
\hline $0.105 \gg$ & $\ldots \ldots \ldots$ & +0.0022 & 2.1 & 2.8 \\
\hline \multicolumn{5}{|l|}{$\mathrm{PbO}$} \\
\hline $0.006 \%$ & $\ldots \ldots$ & +0.0015 & 27.0 & 2.4 \\
\hline $0.013 »$ & $\ldots \ldots \ldots$ & +0.0001 & 0.9 & 1.8 \\
\hline
\end{tabular}

ations in the plagioclase contents. In most cases, however, albite has exoluted in the form of coarse perthite. Table 2 lists the temperatures of formation determined from the curve by Barth (1956) assuming there to be 90 per cent albite in the coexisting plagioclase. The tabulations show that the formation (or rather equilibrium, Dietrich, 1961) took place at fairly uniform temperatures.

The iron content of the feldspars analyzed is very low and has no direct relation to their colour since many feldspars extremely low in iron, such as those from Skinnarvik, Luolamäki and Västilä, are red in colour.

The rubidium content is somewhat higher than that found by Heier and Taylor (1959 a) to be typical for the feldspars in Norwegian

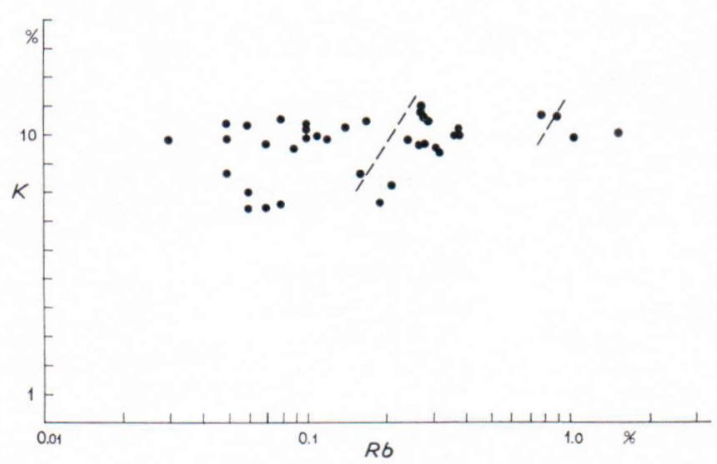

Fig. 1. Relation of $\mathrm{K}$ and $\mathrm{Rb}$. Dashed lines indicate "normal area" according to Heier and Taylor (1959).

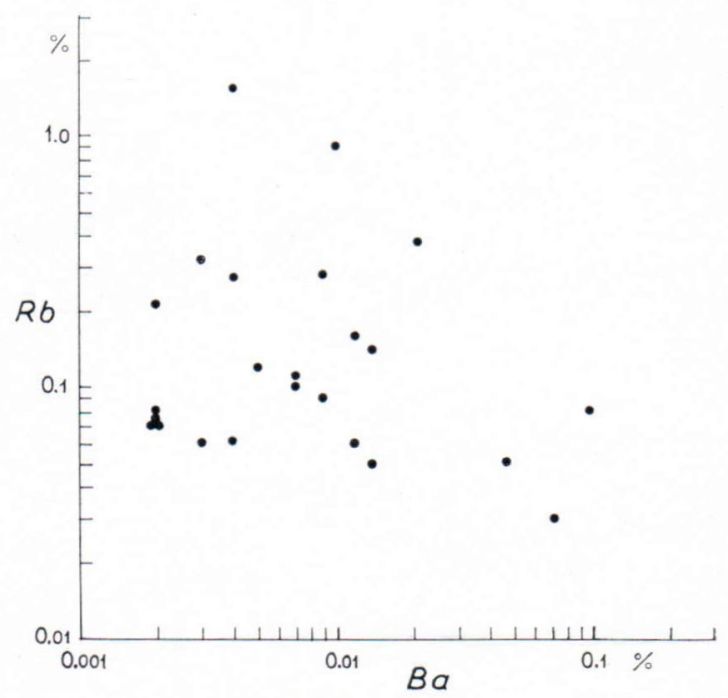

Fig. 2. $\mathrm{Ba} / \mathrm{Rb}$ relationships.

pegmatites (Table 2 and Fig. 1). All but one the $\mathrm{K} / \mathrm{Rb}$ ratios are considerably lower than 240 , but the ratios vary widely, from 370 in a dike at Sillböle down to 7 in a narrow dike sampled in the limestone quarry at Lappeenranta.

A wide spread in the $K / R b$ values was also observed by Herz and Dutra (1966) in Brazil, but they analyzed feldspars from widely different rock types and usually obtained high values.

The barium content in the Finnish feldspars is lower than found by Heier and Taylor (1959 a) or by Herz and Dutra (1966). Consequently, 


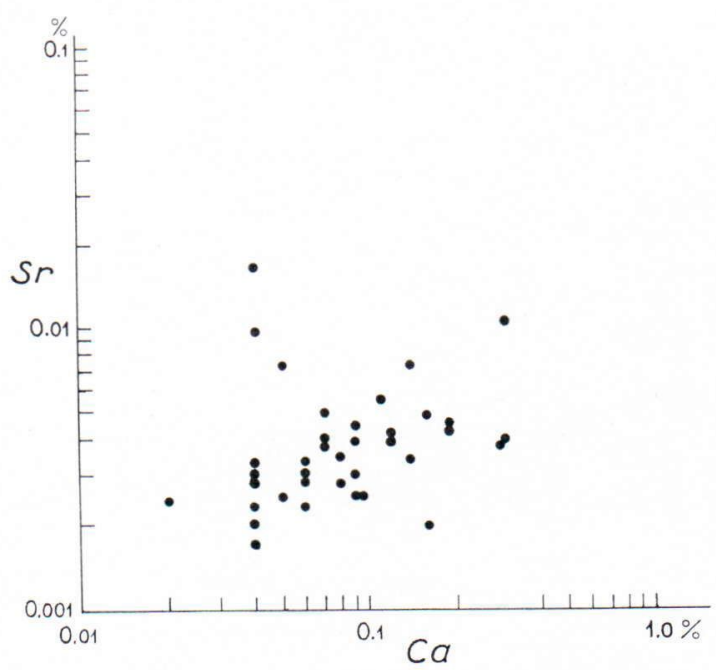

Fig. 3. $\mathrm{Ca} / \mathrm{Sr}$ relationships.

the $\mathrm{Ba} / \mathrm{Sr}$ and especially the $\mathrm{Ba} / \mathrm{Rb}$ ratios (Table 2 and Fig. 2) are much lower than those observed in Norway and Brazil. The Sr contents are usual and do not show any clear correlation with the Ca contents (Fig. 3).

According to Taylor and Heier (1960), barium and rubidium can be considered as the best elements for elucidating fractionation in the igneous rocks. Ba will enter into the $\mathrm{K}$-feldspars in early fractions while $\mathrm{Rb}$ is enriched in the late fractions. Thus, according to these authors, the $\mathrm{Ba} /$ $\mathrm{Rb}$ ratio should be critical for any fractional process. According to them, large Norwegian pegmatites have an average $\mathrm{Ba} / \mathrm{Rb}$ ratio of 0.79 . The Finnish pegmatites have much lower values than that. This is in agreement with lower $\mathrm{K} / \mathrm{Rb}$ ratios found in the Finnish feldspars. Because of the extremely low $\mathrm{Ba}$ contents, the $\mathrm{K} / \mathrm{Rb}$ versus $\mathrm{Ba} / \mathrm{K}$ ratios do not show the clear positive correlation observed by Herz and Dutra (1966).

Cesium seems to be present in great abundance in some of the Finnish feldspars. In most localities where a high Cs is measured, mineral pollucite has also been found to occur, e.g. in Varuträsk, Eräjärvi and Somero. High Cs in pegmatitic feldspar might therefore indicate the presence of pollucite. Consequently, one would expect to find pollucite in the Kaatiala pegmatite quarry, where a wide variation but also a very high Cs content is observed (Table 2). Taylor and Heier (1960) found a clear positive correlation between $\mathrm{Cs}$ and $\mathrm{Rb}$ in feldspars from granites and pegmatites. This correlation is only very weakly evident in the present material.

Lead shows little variation in the feldspars analyzed. The observed $\mathrm{Pb}$ contents agree well with those reported by Heier, Palmer and Taylor (1967) and by Oftedal (1967) for some Norwegian pegmatite feldspars.

\section{Summary}

The X-ray fluorescence method is a useful and convenient technique for the determination of heavy trace elements in feldspar minerals. The deviations observed in the results are caused by the real variation in the chemical composition of the analyzed material rather than by erroneous analytical methods. High $\mathrm{Rb}$ and low $\mathrm{Ba}$ values are characteristic features of the Finnish pegmatite potassium feldspars as are the constant $\mathrm{Pb}$ and $\mathrm{Sr}$ contents. Very little regional variation and characteristics can be observed within the trace element contents determined on the Finnish material.

Acknowledgements. - The authors thank Mr. Väinö Hoffrén (M.Sc.) and Mr. Arvo Löfgren (M.Sc.) of the Geological Survey of Finland for the standard materials. Thanks are also due to Paraisten Kalkkivuori Oy for samples, to Lohjan Kalkkitehdas Oy for instruments used in this work and to the National Research Council for Sciences for economical support.

\section{REFERENCES}

Ahrens, L. H. and TAylor, S. R. (1961). Spectrochemical Analysis. 2nd ed., Addison Wesley.
Barth, T.F. W. (1956). Studies in gneiss and granite. Norsk Vidensk. Akad. Skt., I Mat.-Naturv. Kl. No 1, 1-35. 
Dietrich, R. V. (1961). Comments on the stwo-feldspar geothermometer» and $\mathrm{K}$-feldspar obliquity. Instituto "Lucas Mallada» Inves. Geol., Cursillos y Conferenc 7, $15-20$.

Heier, K. S. (1962). Trace elements in feldspars - a review. Norsk geol. Tidskrift 42 (Feldspar Vol.), $415-454$.

Heier, K. S. and TAYlor, S. R. (1959a). Distribution of $\mathrm{Li}, \mathrm{Na}, \mathrm{K}, \mathrm{Rb}, \mathrm{Cs}, \mathrm{Pb}$ and $\mathrm{Tl}$, in southern Norwegian alkali feldspars. Geocim. et Cosmochim. Acta 15, 284-304.

- (1959b). Distribution of $\mathrm{Ca}, \mathrm{Sr}$ and $\mathrm{Ba}$ in southern Norwegian Pre-Cambrian alkali feldspars. Geochim. et Cosmochim. Acta 17, 286-304.

Heier, K. S., Palmer, P. D. and Taylor, S. R. (1967). Comment on the $\mathrm{Pb}$ distribution in southern Nor- wegian Precambrian alkali feldspars. Norsk geol. Tidskrift 47, 185-189.

Hert., N. and Dutra, C. V. (1966). Trace elements in alkali feldspars, Quadrilátero Ferrifero, Minas Gerais, Brazil. Amer. Miner. 51, 1593-1607.

Oftedal, IVAr (1967). Lead contents in microcline from some granites and pegmatites. Norsk geol. Tidskrift 47, 191-198.

Rankama, K. and Sahama, Th. G. (1960), Geochemistry. Univ. Press., Chicago.

TAYlor, S. R. and Heier, K. S. (1960). The petrological Significance of trace element variations in alkali feldspars. XXI Internat. Geol. Congress Proc., Part XIV, $47-61$.

Manuscript received, January 20, 1968. 